\title{
Potassium Channel Blockers Inhibit Anion Secretion in Cultured Rat Epididymal Epithelium
}

\author{
P. Y. D. WONG \\ Department of Physiology, University of Hong Kong, \\ Sassoon Road, Hong Kong
}

\begin{abstract}
The effect of putative $\mathrm{K}$ channel blockers on anion secretion has been studied in primary monolayer cultures of rat epididymal cells using the short circuit current technique. Under basal conditions, monolayers had a transepithelial potential difference of about $2-3 \mathrm{mV}$, apical side negative and a short circuit current (SCC) of about $2 \mu \mathrm{A} \cdot \mathrm{cm}^{-2}$. The transepithelial resistance was about $500 \Omega \cdot \mathrm{cm}^{2}$. Addition of adrenaline $(0.23 \mu \mathrm{M}$, basolaterally) caused the SCC to rise to a peak value of about $10.5 \mu \mathrm{A} \cdot \mathrm{cm}^{-2}$ and then stabilized at about $4 \mu \mathrm{A} \cdot \mathrm{cm}^{-2}$ after $15 \mathrm{~min}$. This rise in the short circuit current has previously been shown to be due to an increase in net anion secretion from the basolateral to the apical medium. In tissues stimulated with adrenaline, addition of barium $(\mathrm{Ba})$ to the apical side did not affect the adrenaline-induced SCC, but addition to the basolateral side caused a dose-dependent inhibition of the current with an $\mathrm{IC}_{50}$ value (concentration required to inhibit $50 \%$ of the current) of $0.92 \mathrm{~mm}$. At Ba concentration of $5 \mathrm{~mm}$, the adrenaline-induced SCC was completely abolished. There was no effect on transepithelial resistance. Addition of tetraethylamonium (TEA) (16 mM) to the apical or basolateral side had no significant effect on the adrenaline-stimulated SCC. Lidocaine and quinidine inhibited the adrenaline-stimulated SCC when added either to the apical or basolateral bathing solution. The $\mathrm{IC}_{50}$ values for lidocaine were $0.42 \mathrm{~mm}$ and $0.35 \mathrm{~mm}$ for basolateral and apical application, respectively. The $\mathrm{IC}_{50}$ values for quinidine were $0.062 \mathrm{~mm}$ and $0.050 \mathrm{~mm}$ for basolateral and apical application, respectively. In all cases there was no change in tissue resistance. It is proposed that in the basolateral membrane of the epididymal cells, there is a component which is sensitive to putative $\mathrm{K}$ channel blockers. It is likely that it is a $\mathrm{K}$ channel. As in other secretory cells, this channel plays an important role in secretion.
\end{abstract}

Key words: $\mathrm{K}$ channels, $\mathrm{K}$ channel blockers, anion secretion, rat epididymis, cell culture.

Received for publication May 29, 1989 
Primary monolayer cultures of epithelial cells from the rat cauda epididymis secrete chloride and bicarbonate by an electrogenic transport process that appears to have characteristics in common with other anion secreting epithelia (WONG, 1988a). Secretion is stimulated by a number of humoral agents (CUTHBERT and WONG, 1986; WoNG, 1988a), adrenergic agonists (WONG, 1988a; WoNG and CHAN, 1988), and ATP (WONG, 1988c). The disposition of receptors for these agonists display apical/basolateral "sidedness." Receptors for $\beta$-adrenertic agents and prostaglandins are predominately located in the basolateral membrane. Those for bradykinins, angiotensin, and endothelein are present in both the apical and basolateral membrane (see WONG, 1989), whereas receptors for ATP are present exclusively in the apical membrane (WONG, 1989). It is proposed that the apical $\mathrm{P}_{2}$ purinoceptors may serve in a local feedback loop whereby spermatozoa can control the fluidity of their environment through release of sperm ATP (WoNG, 1988c).

Anion secretion induced by $\beta$-adrenergic agonists and possibly other secretomotor agonists are mediated by a rise in intracellular cyclic AMP as second messenger (CUTHBERT and WONG, 1986; WONG, 1989). The primary action of cyclic AMP is to open the apical anion channels, hence allowing efflux of anions and to initiate secretion (WONG, 1988b; WONG and HuANG, 1989). The chloride and bicarbonate concentrations in the cytosol are normally held above electrochemical equilibrium by a basolaterally located $\mathrm{Na}-\mathrm{K}-2 \mathrm{Cl}$ symport, a $\mathrm{Na}-\mathrm{H}$ antiport, and a $\mathrm{Cl}-\mathrm{HCO}_{3}$ antiport (WoNG, 1988a).

In other anion secreting epithelia like the salivary gland (MARUYAMA et al., 1983a; Evans et al., 1986), the lacrimal gland (Trautmann and Marty, 1984), and the exocrine pancreas (MARUYAMA et al., 1983b), the basolaterally located K channels are important elements in secretion. These channels play a central role by recycling $\mathrm{K}$ which has entered the cells via the $\mathrm{Na}-\mathrm{K}-2 \mathrm{Cl}$ symport and the $\mathrm{Na}-\mathrm{K}$ ATPase (Petersen and Gallacher, 1988). They also maintain the membrane repolarized during secretion of anions, a process which tends to depolarize the membrane hence reducing the driving force for $\mathrm{Cl}$ and $\mathrm{HCO}_{3}$ secretion. Since the secretory mechanism of the epididymis is similar to that of other exocrine glands, we are interested in determining if $\mathrm{K}$ channels are present in the basolateral membrane of the epididymal cells and whether they are important in secretion. In this study, we have studied the effects of a few putative $\mathrm{K}$ channel blockers on the adrenalinestimulated anion secretion in primary monolayer cultures of the rat epididymal cells.

\section{METHODS}

Primary monolayer cultures of rat cauda epididymis were grown on millipore filters coated with collagen by methods previously described (CUTHBERT and WONG, 1986; WONG, 1988a, b). After 4 days of culture, the monolayers became confluent and were ready for the measurement of electrogenic ion transport using the short circuit current technique. 
Epididymal monolayers (area $0.4-0.6 \mathrm{~cm}^{2}$ ) were clamped between the two halves of an Ussing chamber with a $0.7 \mathrm{~cm}^{2}$ window. The tissue was short circuited (voltage clamped at zero potential) using W-P Instruments Dual Voltage-Current Clamp Amplifier (DVC 1000) and the short circuit current displayed on a pen recorder (Kipp \& Zonen). The clamp can be used to set the potential, intermittently, at a voltage displaced from zero (usually $0.3 \mathrm{mV}$ ), the resulting current change allowing calculation of the resistance from the ohmic relationship. Very often, the two channels of the amplifier were used simultaneously on parallel monolayers so that studies could be made in the same batch of cells under control and experimental conditions. At the end of the experiments, the area of the monolayers was accurately measured using an IBM computer equipped with a digitizer ( $\left.\operatorname{Hipad}^{\mathrm{TM}}\right)$.

In most situations, monolayers were incubated on both sides with KrebsHenseleit solution $(20 \mathrm{ml})$, gassed with $95 \% \mathrm{O}_{2}$ and $5 \% \mathrm{CO}_{2}$, and warmed to $32{ }^{\circ} \mathrm{C}$, Drugs were added either to the apical or basolateral side of the epithelium. Delivery of drugs to cell surface was instantenous. Experiments were designed to avoid excessive washing of the cell monolayers. The putative $\mathrm{K}$ channel blockers used in the experiments were barium (chloride), tetraethylammonium (chloride), lidocaine, and quinidine (sulfate). All were purchased from Sigma Chemical Company, St. Louis, MO., U.S.A. Barium chloride, tetraethylammonium chloride, and lidocaine were dissolved in distilled water prior to use. Quinidine sulfate was dissolved in $50 \%$ alcohol. The highest concentration of alcohol $(0.25 \%)$ used was found not to affect the SCC when added to the apical or basolateral side of the monolayers.

Statistical analysis. Comparisions between groups of data were made by Student's $t$-test.

\section{RESULTS}

\section{Effect of $\mathrm{Ba}$ on the basal and adrenaline-stimulated short circuit current}

When first clamped in the Ussing chamber, epithelial monolayers formed from the rat cauda epididymis have a transepithelial potential of $2-4 \mathrm{mV}$, a short circuit current of $1-2 \mu \mathrm{A} \cdot \mathrm{cm}^{-2}$, and a transepithelial resistance of about $500 \mathrm{~cm}^{2}$ (WoNG, $1988 \mathrm{a}, \mathrm{b}, \mathrm{c})$. Addition of the $\mathrm{K}$ channel blocker, Ba ( $5 \mathrm{~mm}$ ), to the apical side did not affect the basal short circuit current whereas addition to the basolateral side caused the SCC to fall from $2.20 \pm 0.07 \mu \mathrm{A} \cdot \mathrm{cm}^{-2} \quad($ mean \pm S.E., $n=4)$ to $1.3 \pm 0.06 \mu \mathrm{A} \cdot \mathrm{cm}^{-2}$ (mean \pm S.E., $n=4$ ) (measured when SCC had become steady). Apical application of the same concentration of $\mathrm{Ba}$ had little effect on the basal SCC (Fig. 1). Addition of adrenaline $(0.23 \mu \mathrm{M})$ to the basolateral side resulted in a stimulation of the SCC. The responses were much smaller in monolayers to which $\mathrm{Ba}$ had been added to the basolateral side. The SCC response ( $\triangle \mathrm{SCC}$ measured at the peak of the response) was $2.56 \pm 0.10 \mu \mathrm{A} \cdot \mathrm{cm}^{-2}$ (mean \pm S.E., $n=4$ ) in tissues treated basolaterally with $\mathrm{Ba}$ compared to $10.20 \pm 1.25 \mu \mathrm{A} \cdot \mathrm{cm}^{-2}$ (mean \pm S.E., $n=4$ ) in tissues treated apically with $\mathrm{Ba}$ (Fig. 1). The difference is significant at $p<0.01$. 
(a)
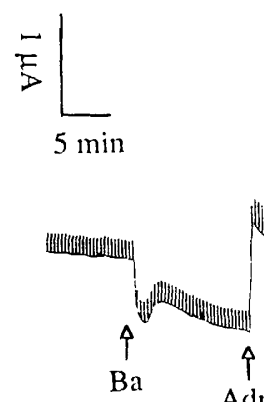

(b)

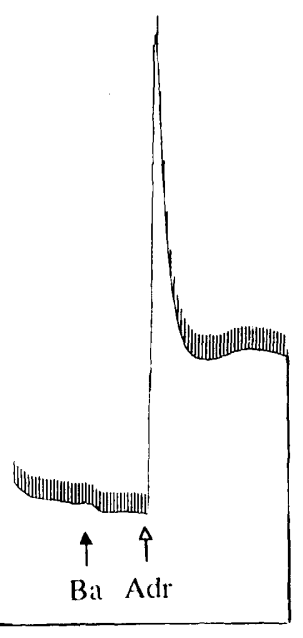

Fig. 1. Short circuit current (SCC) of 2 separate epididymal monolayers, area $0.6 \mathrm{~cm}^{2}$, recorded simultaneously. In (a) $\mathrm{Ba}(5 \mathrm{~mm})$ was added to the basolateral side followed by adrenaline $(0.23 \mu \mathrm{M}$, basolateral). In (b) the same concentration of $\mathrm{Ba}$ was added to the apical side followed by adrenaline $(0.23 \mu \mathrm{M}$, basolateral). Note the response to adrenaline was reduced by the presence of $\mathrm{Ba}$ in the basolateral bathing solution. Transient current pulses were the result of intermittently clamping the potential to $0.3 \mathrm{mV}$. The horizontal line indicates zero SCC. These records are representative of 4 different sets of experiments.

Table 1. Effect of barium on the adrenaline $(0.23 \mu \mathrm{M})$-stimulated short circuit current (SCC) and resistance $(R)$ in cultured epididymal epithelium.

\begin{tabular}{cccc}
\hline Ba $(\mathrm{mM})$ & SCC $\left(\mu \mathrm{A} \cdot \mathrm{cm}^{-2}\right)$ & $\%$ inhibition & $R\left(\Omega \cdot \mathrm{cm}^{2}\right)$ \\
\hline Basolateral application & & & \\
$0^{\mathrm{a}}$ & $4.04 \pm 0.34$ & & $420 \pm 40$ \\
0.5 & $2.30 \pm 0.21^{* *}$ & 43 & $425 \pm 42$ \\
1.5 & $1.31 \pm 0.30^{* * *}$ & 68 & $417 \pm 39$ \\
5 & $0.05 \pm 0.10^{* * *}$ & 99 & $422 \pm 37$ \\
Apical application & & & \\
$0^{\mathrm{a}}$ & $3.82 \pm 0.35$ & & $450 \pm 46$ \\
0.5 & $3.82 \pm 0.33$ & 0 & $443 \pm 65$ \\
1.5 & $3.63 \pm 0.34$ & 5 & $437 \pm 57$ \\
5 & $3.51 \pm 0.32$ & 8 & $435 \pm 62$ \\
\hline
\end{tabular}

Each value shows the mean \pm S.E. of 5 experiments. SCC and resistance measured at steady state after addition of blockers. ${ }^{\text {a }}$ Values measured after the response to adrenaline had stabilized at the plateau level. ${ }^{* *} p<0.005,{ }^{* * *} p<0.001$ when compared to $0 \mathrm{~mm}$ barium. 


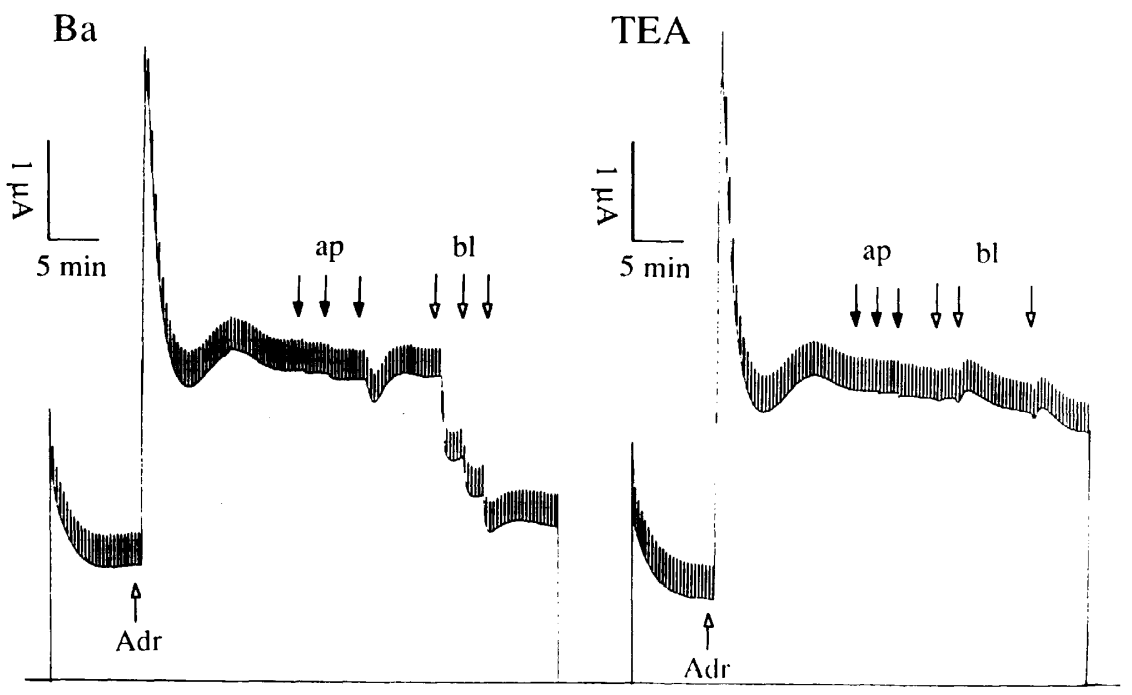

Fig. 2. Short circuit currents (SCC) of 2 separate epididymal monolayers, area $0.6 \mathrm{~cm}^{2}$, recorded simultaneously. The monolayers were challenged with adrenaline ( $\mathrm{Adr}, 0.23 \mu \mathrm{M}$ ) added to the basolateral (bl) sides. When the current had stabilized, $\mathrm{Ba}$ (left) or TEA (right) was added to the apical (ap) then basolateral bathing solutions at the time shown by the arrows to produce the following final concentrations: Ba: 0.5, 1.5, 4 mm (apical and basolateral); TEA: 1, 6, $16 \mathrm{~mm}$ (apical and basolateral). Transient current pulses were the result of intermittently clamping the potential to $0.3 \mathrm{mV}$. The horizontal line indicates zero SCC.

Table 2. Effect of tetraethylammonium (TEA) chloride on the adrenaline $(0.23 \mu \mathrm{M})$-stimulated short circuit current (SCC) and resistance $(R)$ in cultured epididymal epithelium.

\begin{tabular}{rccccccc}
\hline \multirow{2}{*}{$\begin{array}{c}\text { TEA } \\
(\mathrm{mM})\end{array}$} & \multicolumn{2}{c}{ Basolateral application } & & \multicolumn{3}{c}{ Apical application } \\
\cline { 2 - 3 } \cline { 6 - 8 } & $\begin{array}{c}\mathrm{SCC} \\
\left(\mu \mathrm{A} \cdot \mathrm{cm}^{-2}\right)\end{array}$ & $\begin{array}{c}\% \\
\text { inhibition }\end{array}$ & $\begin{array}{c}R \\
\left(\Omega \cdot \mathrm{cm}^{2}\right)\end{array}$ & & $\begin{array}{c}\mathrm{SCC} \\
\left(\mu \mathrm{A} \cdot \mathrm{cm}^{-2}\right)\end{array}$ & $\begin{array}{c}\% \\
\text { inhibition }\end{array}$ & $\begin{array}{c}R \\
\left(\Omega \cdot \mathrm{cm}^{2}\right)\end{array}$ \\
\hline $0^{\mathrm{a}}$ & $3.54 \pm 0.16$ & & $456 \pm 63$ & & $3.52 \pm 0.17$ & & $476 \pm 80$ \\
1 & $3.52 \pm 0.17$ & 0.6 & $446 \pm 70$ & & $3.50 \pm 0.17$ & 0.6 & $475 \pm 76$ \\
6 & $3.38 \pm 0.14$ & 5 & $462 \pm 76$ & & $3.51 \pm 0.16$ & 0.6 & $470 \pm 86$ \\
16 & $3.14 \pm 0.13$ & 11 & $458 \pm 65$ & & $3.40 \pm 0.13$ & 3 & $466 \pm 88$ \\
\hline
\end{tabular}

Each value shows the mean \pm S.E. of 5 experiments. SCC and resistance measured at steady state after addition of blocker. ${ }^{\text {a }}$ Values measured after the response to adrenaline had stabilized at the plateau level. 


\section{Lidocaine}

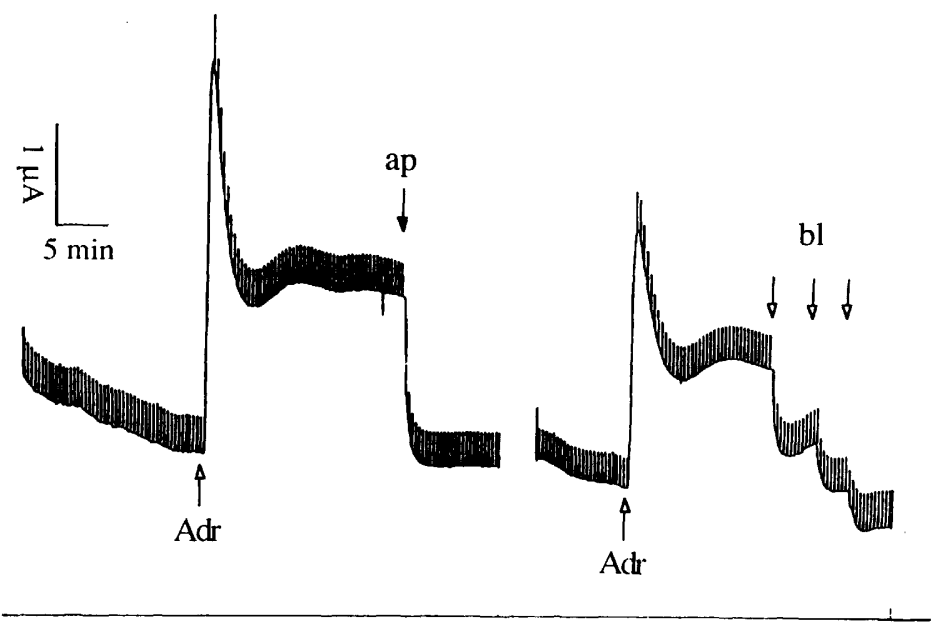

Fig. 3. SCC recording of a single epididymal monolayer, area $0.6 \mathrm{~cm}^{2}$. The tissue was first challenged with adrenaline ( $\mathrm{Adr}, 0.23 \mu \mathrm{M})$ added to the basolateral bathing solution. When the SCC was steady, lidocaine $(1.5 \mathrm{~mm})$ was added to the apical side. The tissue was washed 7 times with fresh Krebs-Henseleit solution and was challenged with adrenaline for the second time. Lidocaine was added to the basolateral medium producing the following final concentrtions: $0.3,0.7,1.5 \mathrm{~mm}$. Transient current pulses were the result of intermittently clamping the potential to $0.3 \mathrm{mV}$. The horizontal line indicates zero SCC.

Table 3. Effect of lidocaine on the adrenaline $(0.23 \mu \mathrm{M})$-stimulated short circuit current (SCC) and resistance $(R)$ in cultured epididymal epithelium.

\begin{tabular}{llllllll}
\hline \multirow{2}{*}{$\begin{array}{c}\text { Lidocaine } \\
(\mathrm{mM})\end{array}$} & \multicolumn{2}{c}{ Basolateral application } & & \multicolumn{3}{c}{ Apical application } \\
\cline { 2 - 3 } \cline { 6 - 8 } & $\begin{array}{c}\mathrm{SCC} \\
\left(\mu \mathrm{A} \cdot \mathrm{cm}^{-2}\right)\end{array}$ & $\begin{array}{c}\% \\
\text { inhibition }\end{array}$ & $\begin{array}{c}R \\
\left(\Omega \cdot \mathrm{cm}^{2}\right)\end{array}$ & & $\begin{array}{c}\mathrm{SCC} \\
\left(\mu \mathrm{A} \cdot \mathrm{cm}^{-2}\right)\end{array}$ & $\begin{array}{c}\% \\
\text { inhibition }\end{array}$ & $\begin{array}{c}R \\
\left(\Omega \cdot \mathrm{cm}^{2}\right)\end{array}$ \\
\hline $0^{\mathrm{a}}$ & $4.01 \pm 0.26$ & & $443 \pm 39$ & & $3.20 \pm 0.17$ & & $499 \pm 23$ \\
0.3 & $3.12 \pm 0.20^{*}$ & 22 & $441 \pm 36$ & & $2.05 \pm 0.15^{* *}$ & 36 & $500 \pm 16$ \\
0.7 & $1.00 \pm 0.32^{* * *}$ & 75 & $439 \pm 39$ & & $0.61 \pm 0.32^{* * *}$ & 81 & $500 \pm 15$ \\
1.50 & $0.07 \pm 0.04^{* * *}$ & 98 & $421 \pm 59$ & & $0.06 \pm 0.04^{* * *}$ & 98 & $492 \pm 27$ \\
\hline
\end{tabular}

Each value shows the mean \pm S.E. of 5 experiments. SCC and resistance measured at

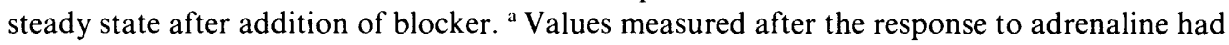
stabilized at the plateau level. ${ }^{*} p<0.05,{ }^{* *} p<0.005,{ }^{* * *} p<0.001$ when compared to $0 \mathrm{~mm}$ lidocaine. 


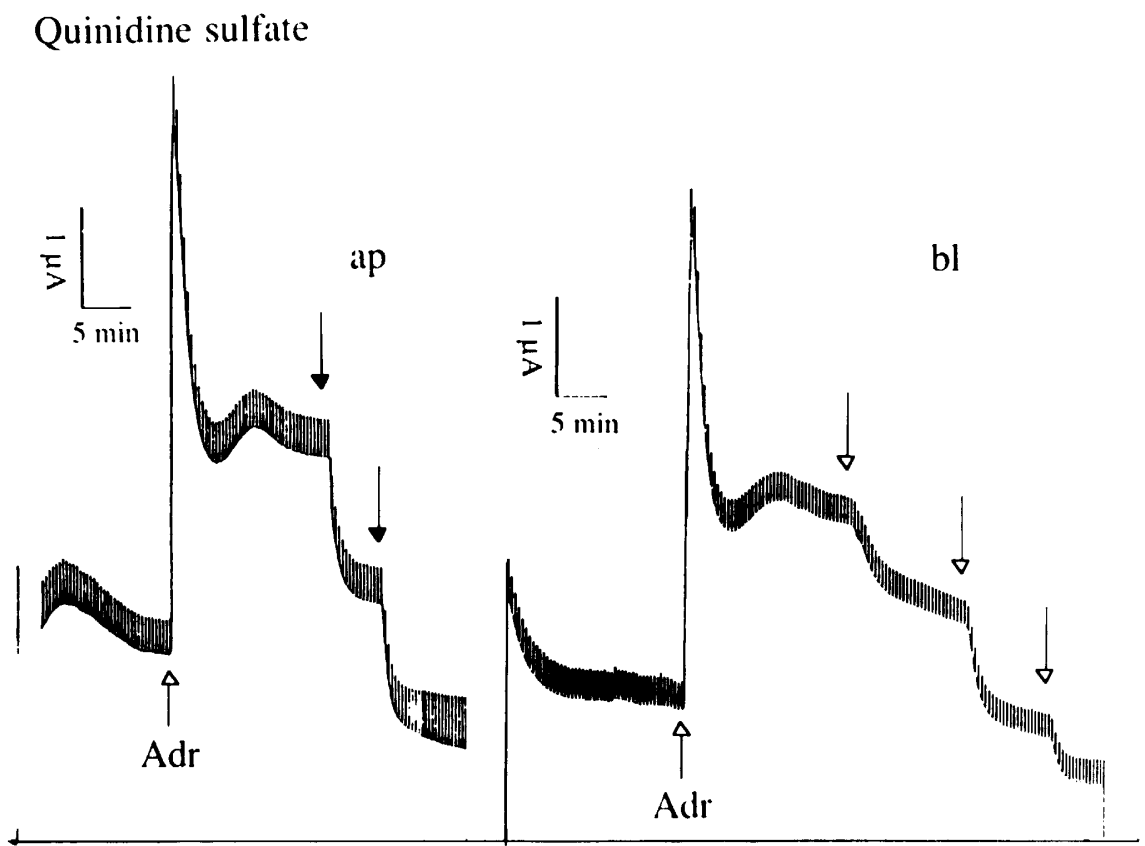

Fig. 4. SCC of 2 separate epididymal monolayers, area $0.6 \mathrm{~cm}^{2}$, recorded simultaneously. The monolayers were challenged with adrenaline $(0.23 \mu \mathrm{M})$ added to the basolateral side. When the current had stabilized, quinidine was added to the apical (left) solution at the time shown by the arrows to produce 0.096 and $0.96 \mathrm{~mm}$ final concentrations. Right: quinidine added to the basolateral bathing solution to achieve $0.048,0.29,0.78 \mathrm{~mm}$ final concentrations. Transient current pulses were the result of intermittently clamping the potential to $0.3 \mathrm{mV}$. The horizontal line indicates zero SCC.

Subsequent experiments were performed in which different doses of Ba were added to monolayers stimulated with adrenaline. In order to avoid excessive washing of the cell monolayers (a process found to compromise the integrity of the monolayers), a method based on addition of cumulative doses was adopted. Adrenaline $(0.23 \mu \mathrm{M})$ added to the basolateral side caused a rise of the SCC to a peak value of about $10.5 \mu \mathrm{A} \cdot \mathrm{cm}^{-2}$ and then stabilized at $4.5 \mu \mathrm{A} \cdot \mathrm{cm}^{-2}$ after about 15 min (Figs. 1-4) (WoNG, 1988a, b). Addition of $\mathrm{BaCl}_{2}$ to the apical side of the epididymal monolayers had no significant effect on the adrenaline-induced SCC and transepithelial resistance (Fig. 2, Table 1). However, addition to the basolateral side caused a dose-dependent inhibition (Fig. 2, Table 1). The concentration required to inhibit $50 \%$ of the adrenaline-induced SCC was $0.92 \mathrm{~mm}$ (geometric mean, $n=5$, $95 \%$ confidence limits $=0.87,1.02$ ). At $5 \mathrm{~mm} \mathrm{Ba}$, the rise in $\mathrm{SCC}$ caused by adrenaline was almost completely abolished (Table 1). There was no change in tissue resistance at all concentrations of $\mathrm{Ba}$ used. 
Table 4. Effect of quinidine sulfate on the adrenaline $(0.23 \mu \mathrm{M})$-stimulated short circuit current $(\mathrm{SCC})$ and resistance $(R)$ in cultured epididymal epithelium.

\begin{tabular}{cccccccc}
\hline \multirow{2}{*}{$\begin{array}{c}\text { Quinidine } \\
\text { sulfate } \\
(\mathrm{mM})\end{array}$} & \multicolumn{3}{c}{ Basolateral application } & & \multicolumn{3}{c}{ Apical application } \\
\cline { 7 - 8 } \cline { 7 - 8 } & $\begin{array}{c}\mathrm{SCC} \\
\left(\mu \mathrm{A} \cdot \mathrm{cm}^{-2}\right)\end{array}$ & $\begin{array}{c}\% \\
\text { inhibition }\end{array}$ & $\begin{array}{c}R \\
\left(\Omega \cdot \mathrm{cm}^{2}\right)\end{array}$ & & $\begin{array}{c}\mathrm{SCC} \\
\left(\mu \mathrm{A} \cdot \mathrm{cm}^{-2}\right)\end{array}$ & $\begin{array}{c}\% \\
\text { inhibition }\end{array}$ & $\begin{array}{c}R \\
\left(\Omega \cdot \mathrm{cm}^{2}\right)\end{array}$ \\
\hline $0^{\mathrm{a}}$ & $5.20 \pm 0.27$ & & $456 \pm 78$ & & $5.81 \pm 0.22$ & & $376 \pm 24$ \\
0.029 & $4.10 \pm 0.24^{*}$ & 21 & $445 \pm 64$ & & $4.22 \pm 0.18^{* *}$ & 27 & $368 \pm 56$ \\
0.048 & $3.00 \pm 0.20^{* *}$ & 42 & $451 \pm 72$ & & $2.81 \pm 0.28^{* *}$ & 52 & $377 \pm 42$ \\
0.29 & $1.78 \pm 0.20^{* *}$ & 85 & $454 \pm 65$ & & $0.58 \pm 0.11^{* *}$ & 90 & $375 \pm 38$ \\
0.78 & $0.04 \pm 0.03^{* *}$ & 99 & $445 \pm 72$ & & $0.05 \pm 0.04^{* *}$ & 99 & $380 \pm 33$ \\
\hline
\end{tabular}

Each value shows the mean \pm S.E. of 5 experiments. SCC and resistance measured at steady state after addition of blocker. ${ }^{\text {a }}$ Values measured after the response to adrenaline had stabilized at the plateau level. ${ }^{*} p<0.02,{ }^{* *} p<0.001$ when compared to $0 \mathrm{~mm}$ quinidine.

(a)

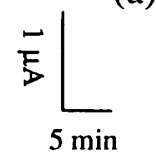

(b)

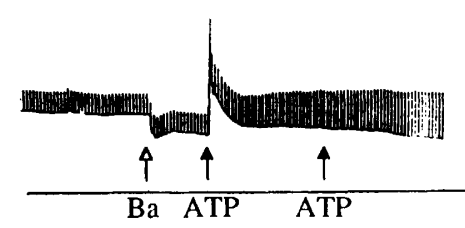

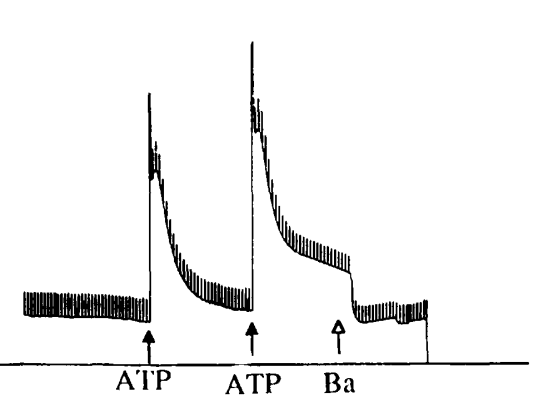

Fig. 5. SCC of 2 separate epididymal monolayers, area $0.4 \mathrm{~cm}^{2}$, recorded simultaneously. In (a) $\mathrm{Ba}(5 \mathrm{mM})$ were first added to the basolateral side followed by apical application of ATP $(0.1$ then $1 \mu \mathrm{M})$. In (b) ATP was added to the apical side ( 0.1 then $1 \mu \mathrm{M})$ followed by basolateral application of $\mathrm{Ba}(5 \mathrm{mM})$. Transient current pulses were the result of intermittently clamping the potential to $0.3 \mathrm{mV}$. The horizontal line indicates zero SCC. These records are representative of 4 different sets of experiments.

\section{Effects of tetraethylammonium (TEA) and other $K$ channel blockers}

Tetraethylammonium (TEA) (1 to $16 \mathrm{~mm}$ ), another $\mathrm{K}$ channel blocker, did not affect the SCC response to adrenaline when the drug was added apically or basolaterally (Fig. 2, Table 2). In all cases there was no change in tissue resistance. Lidocaine and quinidine cause a dose-dependent inhibition of the adrenalinestimulated SCC when added to the apical or basolateral bathing solutions (Figs. 3, 
4, Tables 3, 4). For both agents, the concentration required to inhibit $50 \%$ of the current was similar for both apical and basolateral application. For lidocaine, the $\mathrm{IC}_{50}$ values were $0.42 \mathrm{~mm}$ (geometric mean, $n=5,95 \%$ confidence limits $=0.30,0.40$ ) and 0.35 (geometric mean, $n=5,95 \%$ confidence limits $=0.30,0.40$ ) for basolateral and apical application, respectively. For quinidine, the values were 0.062 (geometric mean, $n=5,95 \%$ confidence limits $=0.059,0.0069$ ) and 0.050 (geometric mean, $n=5,95 \%$ confidence limits $=0.047,0.055$ ) for basolateral and apical application, respectively. There was no change in tissue resistance in all cases (Tables 3,4).

\section{Effect of barium on the secretion response to another agonist}

In other experiments, the effect of $\mathrm{Ba}$ was tested against another secretory agonist, ATP, which is known to stimulate anion secretion in epididymal monolayers. Unlike adrenaline, ATP acts from the apical side of the epithelium (WONG, $1988 \mathrm{c})$. In monolayers treated with $\mathrm{Ba}(5 \mathrm{~mm}$, basolateral application), the response to ATP was reduced by $54 \%$ when responses (measured at the peak of response) to the first dose of ATP $(0.1 \mu \mathrm{M})$ were measured compared to monolayers without pretreatment with Ba (Fig. 5).

\section{DISCUSSION}

It is now known that fluid secretion by exocrine glands is driven by a transepithelial secretion of anions. The cellular mechanism involves an active uptake of chloride across the basolateral membrane and exit of chloride across the apical membrane. Chloride uptake into the cells is mediated by a loop diureticsensitive symport which is energized by the $\mathrm{Na}$ gradient maintained by a ouabainsensitive Na-K ATPase. As $\mathrm{Na}$ runs down its gradient into the cells, some of the energy of the pump is used to concentrate $\mathrm{Cl}$ in the cytosol above electrochemical equilibrium. $\mathrm{Cl}$ then enters the lumen through anion selective channels present in the apical membrane, while $\mathrm{Na}$ is actively extruded into the intercellular space by the Na-K ATPase. The potential difference generated by $\mathrm{Cl}$ secretion provides a driving force for the movement of $\mathrm{Na}$ across the tight junction and the two ions then generate the necessary osmotic gradient for the movement of water across the epithelium. The work of the Na-K ATPase is therefore translated into a transcellular flux of $\mathrm{Cl}$ in a secretory direction (SILva et al., 1977).

In this secretion model, two conductive pathways in the plasma membranes of the secretory cells are important in secretion. They are the basolateral $\mathrm{K}$ channels and the apical chloride channels. Although these channels play a central role in secretion, the $\mathrm{Cl}$ and $\mathrm{K}$ channels from different secretory cells exhibit diverse properties with respect to conductance, sensitivity to blockers and the intracellular messengers that control them. In exocrine glands such as the salivary glands, lacrimal glands, and the exocrine pancreas, the basolateral $\mathrm{K}$ channels are regulated by cytosolic Ca (Maruyama et al., 1983a; Findlay, 1984; Trautmann and Marty, 1984). Activation of channel activity by intracellular $\mathrm{Ca}$ is believed to be the 
primary event in the stimulation-secretion coupling (PETERSEN and MARUYAMA, 1984; see Petersen and Gallacher, 1988). In other secretory epithelia, like the shark rectal gland (GöGELEIN et al., 1987), the basolateral $\mathrm{K}$ channels are not activated by $\mathrm{Ca}$. Recent patch-clamp studies of $\mathrm{K}$ channels in the excised patches of pancreatic duct cell have provided evidence that the channels were activated by exposing the cytoplasmic face of the membrane to ATP and the catalytic subunit of A-kinase (see Gray et al., 1989). In this tissue and in the shark rectal gland and the respiratory epithelium (WELSH, 1987a), cAMP is the intracellular messenger in the stimulus-secretion coupling. Despite the different regulators that control them, the $\mathrm{K}$ channels in different secretory epithelia serve the same purpose: they recycle $\mathrm{K}$ after its uptake by the $\mathrm{Na}-\mathrm{K}-2 \mathrm{Cl}$ symport and Na-K ATPase. It is suggested that the $\mathrm{Na}-\mathrm{K}$ pump, the $\mathrm{Na}-\mathrm{K}-2 \mathrm{Cl}$ symport, and the $\mathrm{K}$ channels act together as one functional unit which effectively transports $\mathrm{Cl}$ into the cytosol with the expenditure of energy from the Na-K ATPase (PeTERSEN and Gallacher, 1988).

The epididymis secretes chloride and bicarbonate electrogenically by mechanisms similar to the other exocrine glands. Secretion is mediated by three basolateral membrane carriers, viz. the $\mathrm{Na}-\mathrm{K}-2 \mathrm{Cl}$ symport, the $\mathrm{Na}-\mathrm{H}$ antiport, and the $\mathrm{Cl}-\mathrm{HCO}_{3}$ antiport (WoNG, 1988a). The concentration of $\mathrm{HCO}_{3}$ (and presumably $\mathrm{Cl}$ ) in the cytosol is held above electrochemical equilibrium. During stimulation there is a rise in intracellular cyclic AMP which causes $\mathrm{HCO}_{3}$ efflux from the cells via the anion channels in the apical membrane (WONG, 1989; WONG and Huang, 1989). These anion channels are blocked by $\mathrm{Cl}$ channel blockers (WONG, 1988b). Although like the shark rectal gland (GREGER et al., 1985), the respiratory epithelium (WELSH, 1987b), and the pancreatic duct (GRAY et al., 1988a), the primary event of the stimulus-secretion coupling appears to be the opening of the anion channels by cyclic AMP, it is expected that there are $\mathrm{K}$ channels in the basolateral membrane and that they play an important role in secretion by providing a pathway for $\mathrm{K}$ efflux.

The findings that the adrenaline-induced anion secretion by the epididymis is inhibited by the putative $\mathrm{K}$ channel blockers appear to agree with the prediction that the $\mathrm{K}$ channels are important for secretion. Secretion is blocked by the application of $\mathrm{Ba}$ to the basolateral but not to the apical side. This result is expected if the $\mathrm{K}$ channels are present in the basolateral membrane. Barium inhibited a part of the basal SCC as well as the adrenaline-induced SCC (Figs. 1, 2), since under basal conditions, epididymal monolayers secrete anion (WONG, 1988a), a process which involves the operation of $\mathrm{K}$ channels. However, secretion was not affected by TEA whether the drug was applied apically or basolaterally (Fig. 2, Table 2). This lack of effect of TEA on secretion may be due to the insensitivity of the $\mathrm{K}$ channels to TEA. This characteristic is shared by the pancreatic duct cells in which the basolateral $\mathrm{K}$ conductance was found to be poorly affected by TEA (50 mM), although $\mathrm{Ba}(5 \mathrm{~mm})$ greatly inhibited it (NovaK and GrEGER, 1988). Indeed, wholecell patch-clamp studies on the rat pancreatic duct cells have shown that the $K$ current was completely blocked by $\mathrm{Ba}$, whereas in the presence of TEA a residual 
current persisted (Gray et al., 1988b). Likewise, in the shark rectal gland, GöGELEIN et al. (1987) reported that the basolateral $\mathrm{K}$ channels are more sensitive to Ba than to TEA. It is not surprising that the $\mathrm{K}$ channels of the epididymis have characteristics similar to those of the pancreatic duct and the shark rectal gland since all these tissues belong to the class of ductal epithelium and they all utilize cyclic AMP as second messenger in the stimulus-secretion coupling.

Secretion of anions by the epididymis was also blocked by other $\mathrm{K}$ channel blockers like quinidine and lidocaine, which block $\mathrm{K}$ channels in other secretory epithelia (VAN DriessChe et al., 1985; GöGeleIN et al., 1987). Unlike Ba, these agents were active when added either to the basolateral or the apical side with similar degrees of potency (Figs.3, 4, Tables 3,4). As these compounds are highly lipophilic, the effects of apical application can still reflect an effect on the basolateral $\mathrm{K}$ channels. However, it is also possible that these blockers have other effects. For example, quinidine has been shown to block $\mathrm{Ca}$ channels in other epithelia (WINDHAGER, 1983). The inhibition of the SCC by quinidine may be due to the blockage of the $\mathrm{Ca}$ channels. However, this possibility seems unlikely since the epididymis does not utilize $\mathrm{Ca}$ as the intracellular messenger and there was no increase in cytosolic Ca during agonist-induced secretion (WoNG, 1989).

In conclusion, this study has shown that the basolateral membrane of the epididymal cells possesses a $\mathrm{Ba}$ (quinidine and lidocaine)-sensitive component which is important for anion secretion by the epididymis. It is likely that this is a $\mathrm{K}$ channel. Unlike the $\mathrm{K}$ channels in some other secretory epithelia (MARUYAMA et al., 1983a, b;Petersen and MaruYama, 1984), the K channels in the epididymis are not sensitive to TEA. In this respect, it is similar to the $\mathrm{K}$ channels in the basolateral membrane of the pancreatic duct cell (GRAY et al., 1988b). It is believed that the K channels play a central role in secretion. During secretion, $\mathrm{K}$ is taken up into the cells by the Na-K-2Cl symport and $\mathrm{Na}-\mathrm{K}$ ATPase. For secretion to continue, the $\mathrm{K}$ which has accumulated in the cytosol has to leave the cells. The basolateral $\mathrm{K}$ channels therefore provide a pathway for K efflux. A more direct approach to verify the presence of a basolateral $\mathrm{K}$ channel in the epididymal cells is now being carried out using patch-clamp technique and by measuring ${ }^{86} \mathrm{Rb}$ efflux from epididymal monolayers loaded with this isotope.

This work was supported by the World Health Organization's Special Programme of Research, Development and Research Training in Human Reproduction under Project 85009 and the University of Hong Kong.

\section{REFERENCES}

Cuthbert, A. W. and Wong, P. Y. D. (1986) Electrogenic anion secretion in cultured rat epididymal epithelium. J. Physiol. (Lond.), 378: 335-346.

Evans, L. A. R., Pirani, D., Cook, D. I., and Young, J. A. (1986) Intraepithelial current flow in rat pancreatic secretory epithelium. Pflügers Arch. (Suppl. 2), 407: S107-S111. Findlay, I. (1984) A patch-clamp study of potassium channels and whole-cell currents in 
acinar cells of the mouse lacrimal gland. J. Physiol. (Lond.), 350: 179-195.

Gögelein, H., Greger, R., and Schlatter, E. (1987) Potassium channels in the basolateral membrane of the rectal gland of Squalus acanthias. Regulation and inhibitors. Pflügers Arch., 409: 107-113.

Gray, M. A., Greenwell, J. R., and Argent, B. E. (1988a) Secretin-regulated chloride channel on the apical plasma membrane of pancreatic duct cells. J. Membr. Biol., 105: $131-142$.

Gray, M. A., Greenwell, J. R., and Argent, B. E. (1988b) Ion channels on pancreatic duct cells and their role in bicarbonate secretion. In: Exocrine Secretion, ed. by WoNG, P. Y. D. and Young, J. A., Hong Kong University Press, Hong Kong, pp. 77-80.

Gray, M. A., Greenwell, J. R., and Argent, B. E. (1989) The role of ion channels in the mechanism of pancreatic bicarbonate secretion. In: Epithelial Secretion of Electrolytes and Water, ed. by Young, J. A. and Wong, P. Y. D., Springer-Verlag, Heidelberg, in press.

Greger, R., Schlatter, E., and Gögelein, H. (1985) Cl channels in the apical cell membrane of the rectal gland "induced" by cAMP. Pfiügers Arch., 403: 446-448.

Maruyama, Y., Gallacher, D. V., and Petersen, O. H. (1983a) Voltage and Ca activated $\mathrm{K}$ channel in basolateral acinar cell membranes of mammalian salivary glands. Nature, 302: 827-829.

Maruyama, Y., Petersen, O. H., Flanagan, P., and Pearson, G. T. (1983b) Quantification of Ca-activated $\mathrm{K}$ channels under hormonal control in pig pancreas acinar cells. Nature, 305: 228-232.

Novak, I. and Greger, R. (1988) Electrophysiological study of transport systems in isolated perfused pancreatic ducts: Properties of the basolateral membrane. Pflügers Arch., 411: 58-68.

Petersen, O. H. and Gallacher, D. V. (1988) Electrophysiology of pancreatic and salivary acinar cells. Annu. Rev. Physiol., 50: 65-80.

Retersen, O. H. and Maruyama, Y. (1984) Calcium-activated potassium channels and their role in secretion. Nature, 307: 693-696.

Silva, P., Stoff, J., Field, M., Fine, L., Forrest, J. N., and Epstein, F. H. (1977) Mechanism of active chloride secretion by shark rectal gland: Role of Na-KATPase in chloride transport. Am. J. Physiol., 233: F298-F306.

Trautmann, A. and Marty, A. (1984) Activation of Ca-dependent K channels by carbamylcholine in rat lacrimal glands. Proc. Natl. Acad. Sci. U.S.A., 81: 611-615.

Van Driessche, W., Hillyard, S. D., and Cantiello, H. (1985) Investigations of basolateral $\mathrm{K}$ channels of the tadpole skin epithelium with noise analysis. Fed. Proc., 44: 1567.

WeLSH, M. J. (1987a) Electrolyte transport by airway epithelia. Physiol. Rev., 67: $1143-1184$.

WeLSH, M. J. (1987b) Effect of phorbol ester and calcium ionophore on chloride secretion in canine tracheal epithelium. Am. J. Physiol., 253: C828-C834.

WindHAGER, E. E. (1983) Regulation role of intracellular calcium ions in epithelial $\mathrm{Na}$ transport. Annu. Rev. Physiol., 45: 519-532.

WONG, P. Y. D. (1988a) Mechanism of adrenergic stimulation of anion secretion in cultured rat epididymal epithelium. Am. J. Physiol., 254: F121-F133.

WonG, P. Y. D. (1988b) Inhibition by chloride channel blockers of anion secretion in cultured epididymal epithelium and intact epididymis of rats. Br. J. Pharmacol., 94: 155-163. 
WONG, P. Y. D. (1988c) Control of anion and fluid secretion by apical $\mathrm{P}_{2}$-purinoceptors in the rat epididymis. Br. J. Pharmacol., 95: 1315-1321.

WonG, P. Y. D. (1989) Electrolyte and fluid transport in the epididymis. In: Epithelial Secretion of Electrolytes and Water, ed. by Young, J. A. and Wong, P. Y. D., SpringerVerlag, Heidelberg, in press.

Wong, P. Y. D. and Chan, T. P. T. (1988) Adrenergic control of electrogenic anion secretion in primary cultures of rat epididymal cells. In: Gastrointestinal \& Hepatic Secretions: Mechanism and Control, ed. by Davison, J. S. and Shaffer, E. A., University of Calgary Press, Calgary, pp. 216-219.

WONG, P. Y. D. and HuANG, S. J. (1989) Intracellular pH measurement in primary monolayer cultures of rat epididymal cells. Pfügers Arch., 413: 414-421. 